\title{
Habitat Use Patterns of Newly Settled Southern Flounder, Paralichthys lethostigma, in Aransas-Copano Bay, Texas
}

\author{
Suraida E. Nañez-James • Gregory W. Stunz • \\ Scott A. Holt
}

Received: 31 January 2008 /Revised: 1 October 2008 / Accepted: 2 October 2008 /Published online: 31 October 2008

(C) Coastal and Estuarine Research Federation 2008

\begin{abstract}
Southern flounder Paralichthys lethostigma populations have been declining in Texas during the past 25 years. Despite their economic importance, little is known about their juvenile habitat requirements. We examined habitat use patterns of newly settled southern flounder in three zones at varying distances from the Aransas Pass inlet in Aransas-Copano Bay by measuring densities using a beam trawl in replicate estuarine habitat types in each zone. Highest abundance occurred near the inlet in vegetated sandy areas and was lowest in nonvegetated muddy bottom in regions furthest from the inlet. We also examined a 25 -year fisheries data set from Texas Parks and Wildlife Department to evaluate long-term spatiotemporal recruitment patterns in Aransas-Copano Bay. These data showed generally low recruitment during the past 25 years with highest abundance near the inlets. Our results support the importance of vegetated habitat
\end{abstract}

\section{S. E. Nañez-James}

NOAA Fisheries,

SEFC/Estuarine Habitats and Coastal Fisheries Center,

646 Cajundome Boulevard,

Lafayette, LA 70506, USA

e-mail: suraida.nanez-james@noaa.gov

G. W. Stunz $(\bowtie)$

Texas A\&M University-Corpus Christi,

Harte Research Institute for Gulf of Mexico Studies,

6300 Ocean Drive,

Corpus Christi, TX 78412, USA

e-mail: greg.stunz@tamucc.edu

\section{S. A. Holt}

University of Texas at Austin Marine Science Institute,

750 Channel View Drive,

Port Aransas, TX 78373, USA

e-mail: sholt@utmsi.edu types, especially those near tidal passes, and suggest a longterm decline in recruitment densities of southern flounder.

Keywords Southern flounder - Nekton - Nursery habitat . $\mathrm{EFH} \cdot$ Settlement $\cdot$ Recruitment

\section{Introduction}

Shallow estuaries are productive marine ecosystems stemming from the abundance of habitat types such as seagrass beds, salt marshes, and nonvegetated bottom (Carr and Adams 1973; Weinstein 1979; Rozas and Minello 1998). A variety of nekton species use these shallow estuarine areas as "nurseries," so called because these areas are often associated with high abundances, growth, and survival for young fish (Heck and Thoman 1984; Kneib 1984; Baltz et al. 1993; Rozas and Minello 1998; Beck et al. 2001; Stunz et al. 2002b). Variation in nekton density among these estuarine habitats is influenced by such factors as habitat complexity, food supply, predation, and habitat selection (Heck and Orth 1980; Baltz et al. 1993; Levin and Hay 1996; Rooker et al. 1998). Evaluating density patterns of fishes in these ecosystems is important for the conservation and proper management of fish stocks. In addition, given the decline of available habitat in many estuaries, a comparative evaluation of fish use of various habitat types is needed (Short and Wyllie-Echeverria 1996; Sheridan et al. 1998).

Information on specific habitat-related densities is necessary for evaluating essential fish habitat (Beck et al. 2001; Rose et al. 2001), and these patterns can serve as indicators of habitat value (Weinstein 1979; Doherty 1982; Baltz et al. 1993; Rozas and Minello 1998; Minello 1999). Specific biotic and abiotic factors can contribute to 
differential abundances among habitat types in shallow estuaries. For example, the proximity to open-water affects habitat use in intertidal marsh habitats (Rozas and Odum 1988; Minello et al. 1994; Peterson and Turner 1994), and for some species, differences in sediment composition can influence fish distributions (Keefe and Able 1994; Moles and Norcross 1995). Therefore, habitats exhibiting suitable biotic and abiotic characteristics should support higher nekton densities during particular life stages (Zimmerman et al. 1990).

Southern flounder Paralichthys lethostigma support an important commercial and recreational fishery throughout the Gulf of Mexico (GSMFC 2000). Texas Parks and Wildlife Department's (TPWD) fishery-independent monitoring program has shown a steady statewide decline in southern flounder populations during the last 25 years (TPWD 2003). The Gulf States Marine Fisheries Commission (GSMFC 2000) has also expressed concern regarding these populations in the Gulf states. Overfishing, bycatch, and declines in nursery habitat quality and quantity are plausible reasons for the decline. Moreover, limited data on specific habitat use, spatial distribution, and especially data on essential nursery habitat requirements for juveniles makes stock assessment difficult.

Despite the economic importance of the southern flounder fishery, only a few studies have evaluated habitat requirements for young juveniles, and most studies have focused on temporal recruitment patterns and distribution based on abiotic parameters. Stokes (1977) found that immigration of juveniles into Aransas Bay, Texas began as temperatures increased to approximately $13.8^{\circ} \mathrm{C}$ and peaked when temperatures ranged from $16.0^{\circ} \mathrm{C}$ to $16.2^{\circ} \mathrm{C}$. He found that January and February were periods of peak recruitment with highest densities of juveniles occurring in Redfish Bay, a primary bay near the major tidal inlet, compared to more remote areas of Aransas Bay (i.e., Copano Bay and St. Charles Bay). King (1971) also found similar temporal recruitment patterns associated with Cedar Bayou, with a greater abundance of larvae and juveniles from January through April. In North Carolina, early juvenile paralichthid flounder preferred low salinity (2-11 \%o) areas (Powell and Schwartz 1977; Walsh et al. 1999; Burke et al. 1991) and migrated to higher saline areas near inlets as they matured. Juvenile recruitment in Barataria Bay, Louisiana also appeared to be dependent on factors related to salinity (Allen and Baltz 1997), suggesting selection for shallow waters with low salinities and high dissolved oxygen levels. Higher abundances of flounder also appear to be associated with muddy bottom substrates composed primarily of silt and clay sediments (Powell and Schwartz 1977; Stokes 1977; Burke et al. 1991). Clearly, a more detailed evaluation is needed to determine the habitat use patterns of young juvenile stages for this flatfish. Thus, the primary goal of this study was to identify potential nursery habitat and examine spatial distribution patterns for juveniles in Aransas-Copano Bay, Texas.

\section{Methods}

Study Site

The study was conducted in the Aransas-Copano Bay system on the Texas Gulf coast (Fig. 1). Other minor and secondary bays in the system include Mission and St. Charles Bays. Saltwater exchange occurs via the Aransas Pass tidal inlet and Cedar Bayou, a small natural tidal inlet (USEPA 1999). The bay system is shallow with a mean depth of $3.0 \mathrm{~m}$. Bay margins slope gently into the deeper central bay and due to a small tidal range, intertidal flats are limited to a 10 - to $20-\mathrm{m}$ margin around the shoreline. The predominant habitat types are nonvegetated bottom, seagrass beds (primarily Halodule wrightii) and intertidal marshes of Spartina alterniflora. Sediment composition along the bay margins consists primarily of sand with small amounts of silt and clay (Britton and Morton 1989).

\section{Large-Scale Patterns of Habitat Use}

Large-scale spatial patterns of habitat use by newly settled southern flounder were examined in Aransas-Copano Bay. Sampling was conducted over a 2-year period during January and March 2004 (two sampling events) and January-March 2005 (three sampling events). The bay system was divided into three zones increasing in distance from Aransas Pass and following a decreasing salinity gradient (Fig. 1). Within each zone, triplicate samples were collected in three separate replicated areas of seagrass (Halodule wrightii), marsh edge (Spartina alterniflora; defined as the ecotonal zone between open-water and emergent vegetation, Baltz et al. 1993; Stunz et al. 2002a), and nonvegetated bottom (open-water). A total of 81 samples (27 samples from each zone) were collected at each sampling event totaling 405 samples over 2 years.

Samples were collected using a beam trawl that consisted of a metal frame with a $1-\mathrm{m}(\mathrm{w}) \times 0.22-\mathrm{m}(\mathrm{h})$ opening fitted with 3-mm conical-shaped mesh net that was approximately $2 \mathrm{~m}$ in length. Nonvegetated bottom was sampled by towing the beam trawl by boat for $100 \mathrm{~m}$ at $7.4 \mathrm{~km} / \mathrm{h}$ covering $100 \mathrm{~m}^{2}$ of bottom as determined by a global positioning system. For seagrass beds, the beam trawl was pulled $20 \mathrm{~m}$ in a random location in the bed covering $20 \mathrm{~m}^{2}$. At the marsh edge, the beam trawl was pulled next to but no more than $1 \mathrm{~m}$ from the emergent vegetation and covered $20 \mathrm{~m}^{2}$. Southern flounder settle from their planktonic phase to the demersal habitat types at 
Fig. 1 Map of the AransasCopano Bay system on the Texas coast showing the three zones sampled. In each zone, triplicate sled tows were made in three areas of marsh edge (filled squares), nonvegetated bottom (filled circles), and seagrass (filled triangles)

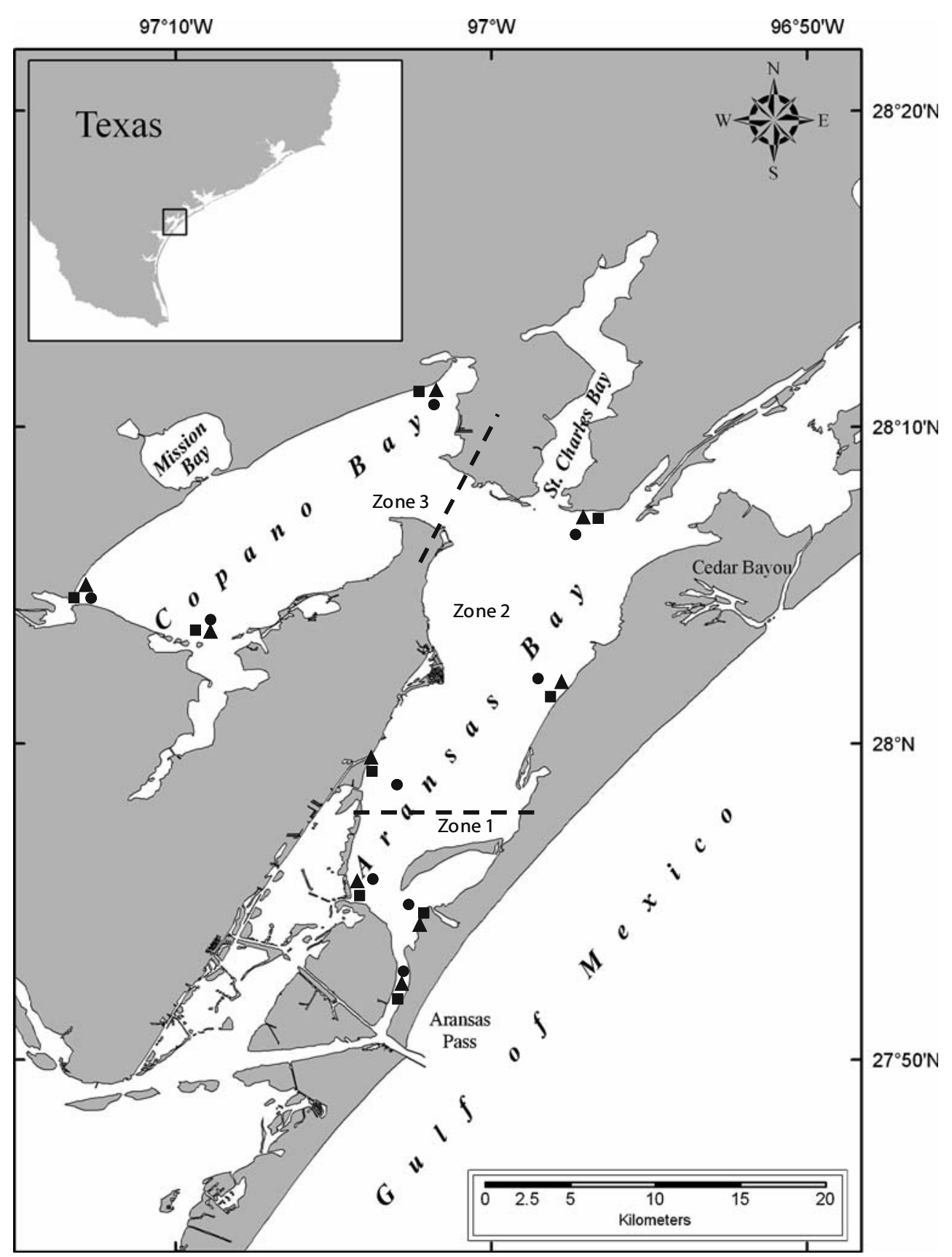

approximately $8-12 \mathrm{~mm}$ standard length (SL). Thus, for this study, we defined newly settled as those fish that were 8-40 mm SL (50 mm TL; TPWD data set). All flatfish were measured to the nearest $0.1 \mathrm{~mm}$ SL.

Water quality parameters, salinity $(\% \circ)$, temperature $\left({ }^{\circ} \mathrm{C}\right)$, dissolved oxygen $(\mathrm{mg} / \mathrm{L})$ and depth $(\mathrm{m})$, were taken at each site using a YSI 6-series datasonde. Samples were roughsorted in the field to remove excess seagrass and algae, fixed in $10 \%$ formalin and were later sorted in the laboratory. Sediment cores were taken from all sites (technique modified from Folk 1980) to examine sediment grain size.

\section{Statistical Analyses}

Large-scale habitat use data were analyzed with analysis of variance (ANOVA, $\alpha=0.05$ ) using the general linear model procedure in SAS 9.1. We used a factorial design with two main fixed treatment effects, zone (distance from inlet, three levels), and habitat type (marsh edge, seagrass, and nonvegetated bottom). The study was conducted over a 2year period, and the sampling design blocked year to control for interannual variability. The distribution of the residuals was analyzed using the UNIVARIATE procedure, and data were transformed $\left(\log _{10}(x+1)\right)$ to reduce hetero- 
scedasticity. Mean differences in size among zones and habitat types were tested using Tukey's HSD $(\alpha=0.05)$. With density patterns, a significant habitat type-zone interaction was detected in the ANOVA model; therefore, we used a one-way main effects model using each zone $\times$ habitat type $\times$ year treatment combination $(n=18)$ as levels in the main treatment with linear contrasts $(\alpha=0.01)$.

A two-factor ANOVA with year as a blocking variable was used to analyze salinity data. Mean temperature and dissolved oxygen levels were calculated for zones and habitat types for both years. A multivariate analysis (PRIMER v.6; Clarke and Gorley 2006) was used to test for significant $(\alpha=0.05)$ differences in sediment composition among habitat types. Because percentage data are not normally distributed, values were arc-sin square roottransformed prior to analysis. A one-way analysis of similarities (ANOSIM, Clarke and Warwick 2001) was used to test for significance of sediment composition among habitats types, which were pooled among all the zones.

\section{Texas Parks and Wildlife Long-term Data Analysis}

Distribution maps for juvenile southern flounder were created from a 25-year Texas Parks and Wildlife bag seine data set from the Aransas-Copano Bay using Environmental Systems Research Institute, Arc GIS 9.1. Samples were collected by TPWD personnel with an 18.3-m bag seine (1.8 $\mathrm{m}$ deep) with a $1.3-\mathrm{cm}$ stretched nylon multifilament mesh in the central bag and a 1.9- $\mathrm{cm}$ stretched mesh in the remaining net (Martinez-Andrade et al. 2005). Only southern flounder $\leq 50 \mathrm{~mm}$ TL collected from the months of December through April (1977-2004) in AransasCopano Bay, Texas, were used to calculate total catch for all years combined. We calculated sampling intensity and catch-per-unit-effort for the months of December through April (1977-2004) and geographically referenced all data. Distributions in the TPWD data set were compared to the results from our beam trawl field collections.

\section{Results}

\section{Large-Scale Patterns of Habitat Use}

We captured a total of 169 juvenile southern flounder during this 2-year study. There was a significant interaction between zones and habitat types (Table 1A); therefore, a one-way main effects ANOVA using each zone $\times$ habitat type $\times$ year combination (18 levels) was conducted (Table 1B). A priori linear contrasts showed that mean densities were significantly higher in zones 1 and 2 than in zone 3 (Table 1B; Fig. 2A). Newly settled flounder showed
Table 1 Analysis of variance tables for southern flounder density (A and B) and size (C) patterns in Aransas-Copano Bay. The main effects were distance from a tidal inlet (zone; three levels) and habitat (three levels). Within each zone, triplicate samples were collected in three separate replicated areas of seagrass, marsh edge, and nonvegetated bottom during the 2-year sampling period. Year was used as a block to control for interannual variation. A priori linear contrasts were used on the main effects ANOVA to test for significant differences in density among zones and habitats (B)

\begin{tabular}{lrlrr}
\hline Source & $d f$ & \multicolumn{1}{l}{ Ss } & \multicolumn{1}{l}{$F$} & \multicolumn{1}{l}{$P$} \\
\hline A. Density & & & & \\
$\quad$ Zone & 2 & 0.007 & 8.66 & $<0.001$ \\
Habitat type & 2 & 0.010 & 12.32 & $<0.001$ \\
Zone $\times$ Habitat Type & 4 & 0.004 & 2.43 & 0.047 \\
Year (Block) & 1 & 0.006 & 16.57 & $<0.001$ \\
$\quad$ Residual & 395 & 0.154 & & \\
B. Density & & & & \\
Main effects & 17 & 0.035 & 5.47 & $<0.001$ \\
Zone 1 vs. zone 2 & 1 & 0.000 & 0.04 & 0.840 \\
Zone 1 vs. zone 3 & 1 & 0.006 & 16.06 & $<0.001$ \\
Zone 2 vs. zone 3 & 1 & 0.007 & 17.72 & $<0.001$ \\
Marsh edge vs. Seagrass & 1 & 0.001 & 2.28 & 0.131 \\
Marsh edge vs. nonvegetated & 1 & 0.011 & 28.57 & $<0.001$ \\
Seagrass vs. nonvegetated & 1 & 0.006 & 14.70 & 0.001 \\
$\quad$ Residual & 387 & 0.146 & & \\
C. Size & & & & \\
Zone & 2 & 0.189 & 5.95 & 0.003 \\
Habitat type & 2 & 0.316 & 9.98 & $<0.001$ \\
Zone × Habitat type & 4 & 0.070 & 1.10 & 0.357 \\
Year (Block) & 1 & 0.134 & 8.43 & 0.004 \\
Residual & 159 & 2.518 & & \\
\hline
\end{tabular}

a strong selection for vegetated habitats (either marsh edge or seagrass) over nonvegetated bottom, and this pattern was consistent across zones. Moreover, densities between marsh edge and seagrass were not significantly different (Table 1B; Fig. 2B).

There was a significant difference in mean size of juvenile flounder among zones and habitat types (Table 1C). However, there was not a significant interaction in mean size between zones and habitat types (Table 1C). Mean juvenile length varied among zones, with the size $( \pm \mathrm{SE})$ in zone $2(16.2 \pm 0.81 \mathrm{~mm})$ and zone $3(17.3 \pm$ $1.83 \mathrm{~mm})$ significantly larger than $(12.7 \pm 0.54)$ in zone 1 (Fig. 3A). Additionally, the mean size was significantly different among all three habitat types (Fig. 3B). The mean size was highest in marsh edge $(17.2 \pm 0.76 \mathrm{~mm})$, followed by seagrass $(12.6 \pm 0.5 \mathrm{~mm})$ and smallest in non-vegetated bottom $(10.0 \pm 0.32 \mathrm{~mm}$; Fig. 3B).

\section{Environmental Parameters}

Mean salinities within zones for January and March 2004 and January-March 2005 were consistent with a decreasing salinity gradient integrated into the sampling design. 
a

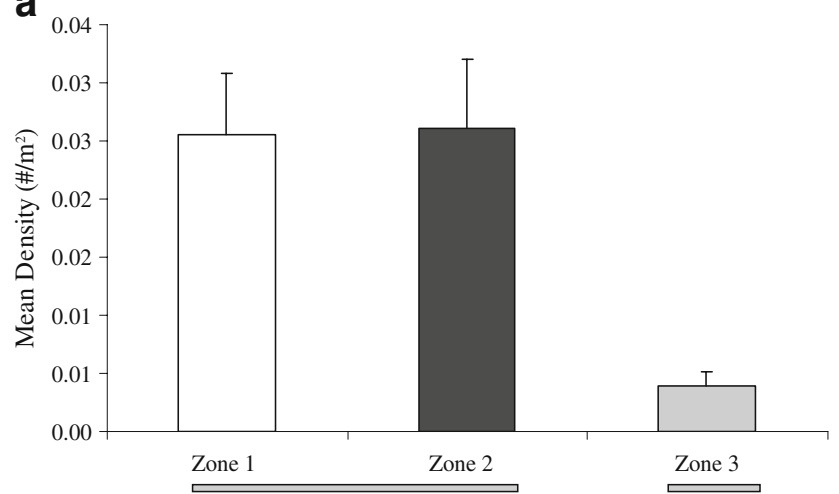

b

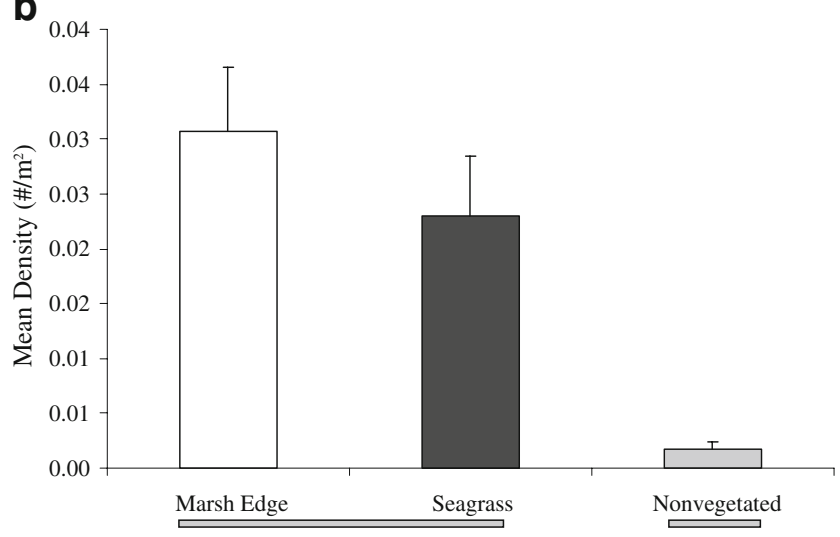

Fig. 2 a Mean density ( \pm SE) of newly settled southern flounder $(N=$ 169) collected with a beam trawl from zone 1, zone 2 , and zone 3 from all samples collected in Aransas-Copano Bay during the recruitment period (January-March) in 2004 and 2005. b Mean density $( \pm$ SE) of newly settled southern flounder collected with a beam trawl from marsh edge, seagrass, and nonvegetated habitat types from all samples collected in Aransas-Copano Bay during the recruitment period (January-March) in 2004 and $2005(N=169)$. Horizontal lines below the bars show differences among habitat and zone types, and the bars sharing lines are not significantly different (Tukey's post hoc test $\alpha=0.05$ )

Salinity levels were higher in 2004 than in 2005 due to increased rainfall in 2005. A two-factor ANOVA with year as a blocking variable showed no significant interaction for means of salinity between zones and habitat type $(d f=4, F=$ $0.14, P=0.9684)$. Mean salinity did not differ among habitat types $(d f=2, F=1.09, P=0.3402)$, but there was a significant difference among the three different zones $(d f=$ 2, $F=136.31, P<0.001$ ). Both years (Table 2) showed the same trend with highest salinities occurring in zone 1 (mean \pm SE; $2004=26.7 \pm 0.6 ; 2005=18.7 \pm 0.9$ ), followed by zone $2(2004=21.7 \pm 0.3 ; 2005=11.4 \pm 0.8)$ and lowest in zone $3(2004=13.6 \pm 0.5 ; 2005=6.7 \pm 0.4)$. Mean temperatures ranged from $16.4^{\circ} \mathrm{C}$ to $22.4^{\circ} \mathrm{C}$, and the patterns were similar among zones and habitat types throughout the study. Mean dissolved oxygen levels ranged between 5.0 and $10.5 \mathrm{mg} / \mathrm{L}$ and were similar among zones, habitat types, and between years.

\section{Sediment Grain Size Analysis}

Sediment composition varied significantly between habitat types (ANOSIM, $R=0.151, P=0.024$ ). Nonvegetated bottom was significantly different from both marsh edge (ANOSIM, $P=0.021)$ and seagrass $(P=0.025)$, and marsh edge and seagrass were similar $(P=0.802)$. Nonvegetated bottom had a higher percent composition of silt and clay (35.6\% and $20.6 \%$, respectively) than both marsh edge $(9.2 \%$ and $4.4 \%$, respectively) and seagrass $(4.6 \%$ and $3.0 \%$, respectively; Fig. 4).

\section{Texas Parks and Wildlife Long-Term Data Analysis}

The TPWD bag seine program provided thorough coverage of most areas along the shorelines over the 25 -year period
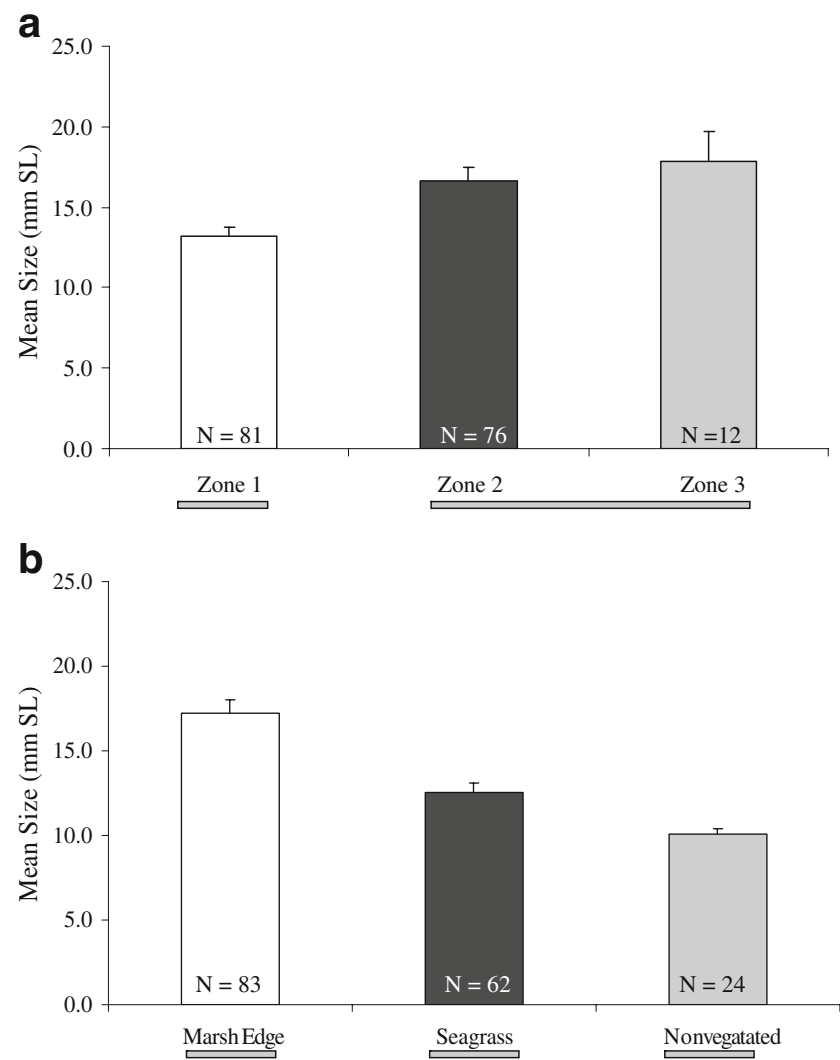

Fig. 3 a Mean length (mm SL \pm SE) of newly settled southern flounder collected with a beam trawl from zone 1, zone 2, and zone 3 from all samples collected in Aransas-Copano Bay during the recruitment period (January-March) in 2004 and 2005. Overall number of fish captured per zone is indicated at the base of bars. b Mean length ( $\mathrm{mm}$ $\mathrm{SL} \pm \mathrm{SE}$ ) of newly settled southern flounder collected with a beam trawl from marsh edge, seagrass, and nonvegetated habitat types from all samples collected in Aransas-Copano Bay during the recruitment period (January-March) in 2004 and 2005. Overall, number of fish captured per habitat type is indicated at the base of bars. Horizontal lines below the bars show differences among habitat and zone types (Tukey's post hoc test $\alpha=0.05$ ) 
Table 2 Mean physical parameter measurements $( \pm$ SE) for habitats in each zone, January and March 2004 and January-March 2005 . The overall mean for each parameter is also calculated by combining the habitat measurements within each zone

\begin{tabular}{|c|c|c|c|c|c|}
\hline Year & Parameter & Marsh Edge & Seagrass & Nonvegetated & Overall mean \\
\hline \multicolumn{6}{|c|}{ Zone 1} \\
\hline \multirow[t]{3}{*}{2004} & Salinity (ppt) & $28.1 \pm 0.9$ & $26.2 \pm 0.9$ & $25.9 \pm 1.4$ & $26.7 \pm 0.6$ \\
\hline & Temperature $\left({ }^{\circ} \mathrm{C}\right)$ & $22.2 \pm 0.4$ & $19.5 \pm 0.7$ & $17.0 \pm 0.4$ & $19.6 \pm 0.6$ \\
\hline & Dissolved oxygen $(\mathrm{mg} / \mathrm{L})$ & $10.5 \pm 1.0$ & $9.6 \pm 0.3$ & $8.6 \pm 0.2$ & $9.6 \pm 0.4$ \\
\hline \multirow[t]{3}{*}{2005} & Salinity (ppt) & $18.0 \pm 1.3$ & $18.1 \pm 1.6$ & $20.1 \pm 2.1$ & $18.7 \pm 0.9$ \\
\hline & Temperature $\left({ }^{\circ} \mathrm{C}\right)$ & $18.3 \pm 1.4$ & $17.6 \pm 1.4$ & $17.7 \pm 1.0$ & $17.9 \pm 0.7$ \\
\hline & Dissolved oxygen $(\mathrm{mg} / \mathrm{L})$ & $9.5 \pm 1.1$ & $8.8 \pm 0.5$ & $9.1 \pm 0.6$ & $9.1 \pm 0.4$ \\
\hline \multicolumn{6}{|l|}{ Zone 2} \\
\hline \multirow[t]{3}{*}{2004} & Salinity (ppt) & $22.4 \pm 0.5$ & $21.9 \pm 0.4$ & $20.8 \pm 0.7$ & $21.7 \pm 0.3$ \\
\hline & Temperature $\left({ }^{\circ} \mathrm{C}\right)$ & $17.7 \pm 1.5$ & $16.4 \pm 1.6$ & $16.5 \pm 1.5$ & $16.7 \pm 0.8$ \\
\hline & Dissolved oxygen $(\mathrm{mg} / \mathrm{L})$ & $9.8 \pm 0.2$ & $9.4 \pm 0.3$ & $8.8 \pm 0.2$ & $9.3 \pm 0.2$ \\
\hline \multirow[t]{3}{*}{2005} & Salinity (ppt) & $10.5 \pm 1.2$ & $10.2 \pm 1.2$ & $13.6 \pm 1.8$ & $11.4 \pm 0.8$ \\
\hline & Temperature $\left({ }^{\circ} \mathrm{C}\right)$ & $20.4 \pm 1.7$ & $19.5 \pm 1.6$ & $17.4 \pm 1.1$ & $19.1 \pm 0.8$ \\
\hline & Dissolved oxygen $(\mathrm{mg} / \mathrm{L})$ & $10.6 \pm 0.9$ & $10.3 \pm 0.6$ & $5.0 \pm 0.9$ & $8.6 \pm 0.7$ \\
\hline \multicolumn{6}{|c|}{ Zone 3} \\
\hline \multirow[t]{3}{*}{2004} & Salinity (ppt) & $13.4 \pm 0.8$ & $13.6 \pm 0.9$ & $13.9 \pm 0.8$ & $13.6 \pm 0.5$ \\
\hline & Temperature $\left({ }^{\circ} \mathrm{C}\right)$ & $16.9 \pm 1.0$ & $16.8 \pm 1.0$ & $16.8 \pm 1.1$ & $16.8 \pm 0.6$ \\
\hline & Dissolved oxygen $(\mathrm{mg} / \mathrm{L})$ & $9.8 \pm 0.3$ & $10.1 \pm 1.0$ & $8.9 \pm 0.4$ & $9.6 \pm 0.4$ \\
\hline \multirow[t]{3}{*}{2005} & Salinity (ppt) & $6.7 \pm 0.7$ & $6.5 \pm 0.7$ & $6.9 \pm 0.6$ & $6.7 \pm 0.4$ \\
\hline & Temperature $\left({ }^{\circ} \mathrm{C}\right)$ & $20.8 \pm 1.4$ & $20.3 \pm 1.4$ & $17.8 \pm 1.1$ & $19.6 \pm 0.8$ \\
\hline & Dissolved oxygen $(\mathrm{mg} / \mathrm{L})$ & $9.3 \pm 0.2$ & $9.2 \pm 0.2$ & $8.3 \pm 0.7$ & $9.0 \pm 0.3$ \\
\hline
\end{tabular}

(Fig. 5A), and newly settled southern flounder showed clear spatial distribution patterns. Catch-per-unit-effort (catch per hectare) of newly settled fish was highest in areas near the tidal inlets (ca. within $12 \mathrm{~km}$ of Aransas Pass Inlet and Cedar Bayou), but during the 25-year period, there was consistently low overall densities (Fig. 5B). These spatial patterns are similar to our beam trawl field surveys, where we observed generally low abundance of flounder with the

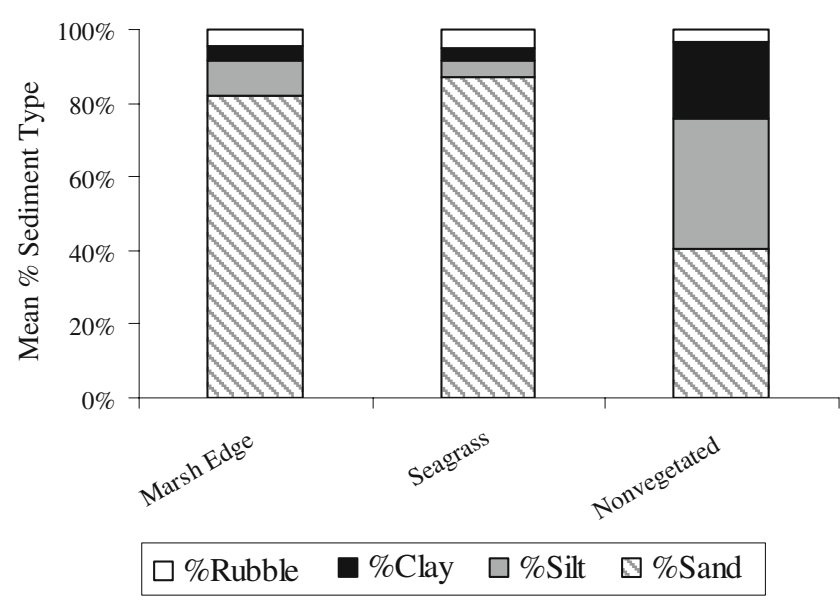

Fig. 4 Mean percent $( \pm \mathrm{SE})$ sediment composition (percent rubble, clay, silt, and sand) for all habitat types (marsh edge, seagrass, and nonvegetated bottom) collected at flounder sampling sites in AransasCopano Bay in June $2004(N=81)$ highest densities in regions near tidal inlets in seagrasses and marsh edge habitat types.

\section{Discussion}

Spatial distribution of newly settled juvenile southern flounder was related to distance from the tidal pass and habitat type. Highest densities were found in more saline vegetated habitats near the pass, within the primary bay. Lowest densities were observed in less saline areas farthest from the pass and were associated with nonvegetated bottom. Stokes (1977) reported similar patterns in other Texas estuaries, where southern flounder immigrated and settled into areas within the primary bay near the pass, as opposed to more remote areas farther from the tidal inlet. Flounder studies in North Carolina and Louisiana reported the opposite, with higher abundance at lower salinities in upper-bay regions (Burke et al. 1991; Allen and Baltz 1997) for several paralichthid flounder species, suggesting these patterns were due to fewer predators at these sites

Fig. 5 a Map of Aransas-Copano Bay on the Texas coast showing bag seine sampling intensity (total count of sampling events per site) conducted by Texas Parks and Wildlife from all December, January, February, March, and April months (1977-2004). b Map of AransasCopano Bay system showing catch per hectare (CPUE) of southern flounder ( $\leq 50 \mathrm{~mm}$ TL) captured with a bag seine by Texas Parks and Wildlife from all December-April data from 1977 through 2004 

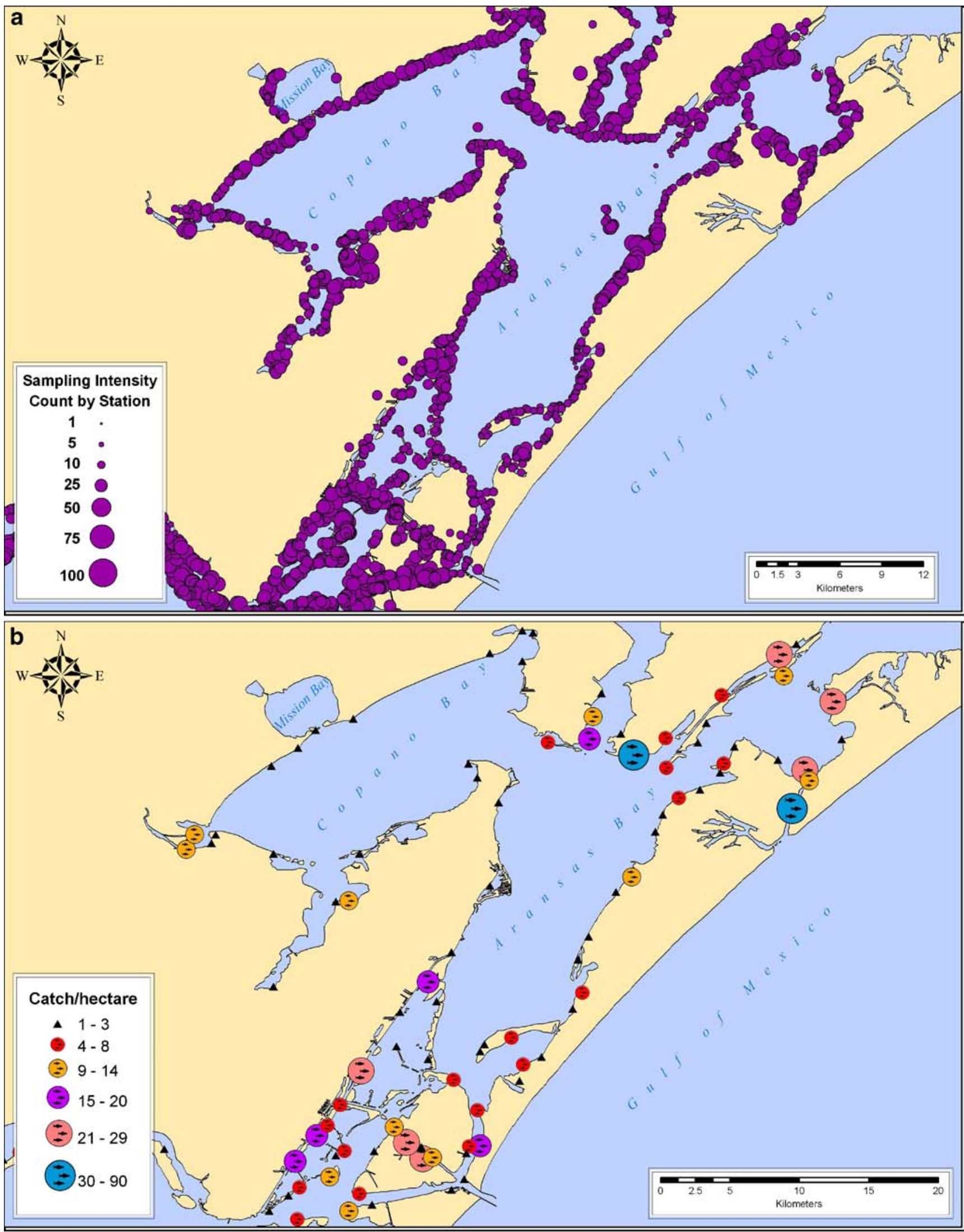
(Rozas and Hackney 1984). However, results from our study suggest that areas nearest the tidal inlet are the most important settlement sites for newly recruiting flounder.

Densities of newly settled juvenile southern flounder were also influenced by habitat type. Seagrass beds and marsh edge supported significantly higher densities compared to nonvegetated bottom, suggesting vegetated habitats may be functioning as important nursery areas for these newly settled fish. This pattern was consistent in all zones with the highest densities in either marsh edge or seagrass. High numbers of southern flounder in vegetated habitats were also reported in Aransas Bay by Stokes (1977). These areas, such as seagrass beds and marshes, are known to support higher densities of several fishes compared to nonvegetated habitats (Bell et al. 1988; Boehlert and Mundy 1988; Rozas and Minello 1997; Stunz et al. 2002a; Heck and Orth 2003). They provide complex structure that facilitates avoidance of predators while supplying an abundance of accessible prey, in turn, contributing to increased survival and growth rates of fishes (Rozas and Odum 1988; Minello and Zimmerman 1992; Sogard 1992; Rooker et al. 1998; Stunz et al. 2002b).

The mean size of southern flounder varied among zones. We collected smaller fish in zones closest to the inlet, and size became progressively larger with increasing distance from the inlet, suggesting variable growth rates among zones and/or migration toward the headwaters of the estuary after settlement. Smaller mean size in areas near the pass may be attributed to newer, smaller recruits migrating into the estuaries from offshore spawning sites (King 1971; Brown et al. 2004), while older recruits are moving and growing as they migrate farther and disperse throughout the estuary. Alternatively, mean size could be related to differences in mean salinity among zones. Other flatfishes, such as winter flounder (Psuedopleuronectes americanus), have faster growth in low salinities (Manderson et al. 2002). Such low salinity areas may provide refuge from stenohaline marine predators (Rozas and Hackney 1984) increasing survival and perhaps growth and contributing to an overall higher mean size of flounder in these areas. Based on density patterns observed, our results suggest the size distributional patterns are the primary result of migration as opposed to differential growth.

Mean size of southern flounder was highest in vegetated habitats. Size differences between vegetated and nonvegetated sites may be an indication of differential growth and/or movement between habitat types. Vegetated habitats are structurally complex providing abundant prey and refuge from predators (Rozas and Odum 1988; Sogard 1992; Kneib 1993; Rooker et al. 1998). The quality and quantity of complex habitats may lead to faster growth and lower mortality (subsequently better growth and survival) and are important to successful recruitment into adult populations (Houde 1987; Sogard 1992; Kneib 1993; Gibson 1994; Levin 1994). Our results also showed higher mean size in marsh edge compared to seagrass and nonvegetated bottom. These size differences may be attributed to marsh and seagrass having a higher prey abundance (Teal 1962; Boesch and Turner 1984; Rozas and LaSalle 1990; Minello and Zimmerman 1992) contributing to faster growth rates. Moreover, Walsh et al. (1999) also suggested that the characteristic flat body shape and benthic lifestyle of flatfish makes it difficult to maneuver through seagrass beds, and this may limit foraging ability. Because we did not examine growth as an indicator of quality habitat, further research is needed to examine possible differences in growth rates among shallow estuarine habitat types.

Sediment composition was also a factor affecting the distribution of southern flounder. The differences in fish density reflected the difference in sediments between vegetated and nonvegetated habitats. Sediments in seagrass and marsh edge were primarily composed of sand with only smaller amounts of silt and clay, while nonvegetated habitats exhibited a muddy substrate (silt/clay composition with small amounts of sand). The sediment composition patterns observed among habitats were consistent with the substrate composition reported previously in Texas bays (Britton and Morton 1989). In our study, we found the highest density of juveniles on sand, which was contrary to findings from other studies in Texas, North Carolina, and Louisiana. Those studies reported southern flounder predominately settled on muddy substrates (silt/clay) (Powell and Schwartz 1977; Burke et al. 1991; Burke et al. 1998), which may provide more suitable substrate for flatfish to easily bury, camouflage, and protect their flat bodies from predators, as opposed to sandy bottoms (Tanada 1990; Moles and Norcross 1995; Nasir and Poxton 2001). It is possible the positive effects of vegetated habitat types, such as protection from predation or greater food availability, were more important than the potential negative effects of settling on less coarse sediments. More research is needed to examine the interactions among bottom types and sediment characteristics, prey abundance, and predation risk in determining flounder distribution and abundance.

In addition to our specific habitat use characterizations, we used a long-term monitoring data set provided by Texas Parks and Wildlife Department to examine distribution and abundance patterns of southern flounder over a large spatial scale independent of habitat type. These spatial patterns observed were similar to our beam trawl field collection study with highest catch-per-unit effort (catch per hectare) of newly settled flounder in areas near the tidal inlets (within $\sim 12 \mathrm{~km}$ of Aransas Pass Inlet and Cedar Bayou). These data also suggest relatively low densities of newly 
settled juveniles over the past three decades. The temporal coverage of the data set includes periods of both high and low adult abundance, while recruiting densities remained consistently low. Thus, the observed low recruitment densities data may be useful in explaining why the recovery of this species has been problematic even with stricter harvest regulations. Moreover, results from our study show that by combining specific habitat use data with monitoring programs, short- and long-term evaluations are possible to aid in identifying and understanding fish habitat use patterns.

In summary, seagrass and marsh edge habitat types with sandy sediments, especially near tidal inlets, support the greatest densities of newly settled southern flounder in Aransas-Copano Bay and may be important "nurseries." This information will be important for managers to evaluate the relative value of certain areas as essential fish habitat for this species as well as evaluating the causes for the fishery decline. Additionally, more research is needed to evaluate the link between the patterns observed and other factors affecting recruitment in Texas estuaries. By examining the functional relationships between habitat use and fish productivity in terms of survival and growth, scientists can further examine factors influencing the abundance of southern flounder populations.

Acknowledgements We gratefully acknowledge Texas Sea Grant (Grant no. NA16RG078), Coastal Conservation Association and Texas A\&M University - Corpus Christi for funding this project. We would also like to thank UTMSI, particularly Dr. Paul Montagna and Rick Kalke, for their assistance with sediment analysis, as well as Cameron Pratt and Jason Williams for their extensive work in the field and the lab. A special thank you to Dr. Mark Fisher, TPWD, for aiding us in obtaining monitoring data and John Wood, HRI, for helping with the spatial analysis. We greatly appreciate the time and effort, comments, suggestions, and advice from the editors and anonymous reviewers that substantially improved this manuscript. Finally, many thanks to the Fisheries Ecology Lab, especially Megan Reese, John Froeschke, Bridgette Froeschke, and Jason James along with many other undergraduates, graduates, and volunteers for their invaluable assistance in the field and laboratory.

\section{References}

Allen, R.L., and D.M. Baltz. 1997. Distribution and microhabitat use by flatfishes in a Louisiana estuary. Environmental Biology of Fishes 50: 85-103. doi:10.1023/A:1007398517163.

Baltz, D.M., C. Rakocinski, and J.W. Fleeger. 1993. Microhabitat use by marsh-edge fishes in a Louisiana estuary. Environmental Biology of Fishes 36: 109-126. doi:10.1007/BF00002790.

Beck, M.W., K.L. Heck, K.W. Able, D.L. Childers, D.B. Eggleston, B.M. Gillanders, B. Halpern, C.G. Hays, K. Hoshino, T.J. Minello, R.J. Orth, P.F. Sheridan, and M.R. Weinstein. 2001. The identification, conservation, and management of estuarine and marine nurseries for fish and invertebrates. Bioscience 51: 633-641.
Bell, J.D., A.S. Steffe, and M. Westoby. 1988. Location of seagrass beds in estuaries: effects on associated fish and decapods. Journal of Experimental Marine Biology and Ecology 122: 127-146. doi:10.1016/0022-0981(88)90180-3.

Boehlert, G.W., and B.C. Mundy. 1988. Roles of behavioral and physical factors in larval and juvenile fish recruitment to estuarine nursery areas. American Fisheries Society Symposium 3: 51-67.

Boesch, D.F., and R.E. Turner. 1984. Dependence of fishery species on salt marshes: the role of food and refuge. Estuaries 7: 460 468. doi:10.2307/1351627.

Britton, J.C., and B. Morton. 1989. Shore ecology of the Gulf of Mexico. Austin, Texas: University of Texas Press.

Brown, C.A., S.A. Holt, G.A. Jackson, D.A. Brooks, and G.J. Holt. 2004. Simulating larval supply to estuarine nursery areas: how important are physical processes to the supply of larvae to the Aransas Pass Inlet? Fish Oceanography 13: 181-196. doi:10.1111/j.1365-2419.2004.00285.x.

Burke, J.S., J.M. Miller, and D.E. Hoss. 1991. Immigration and settlement pattern of Paralichthys dentatus and P. lethostigma in an estuarine nursery ground, North Carolina, U.S.A. Netherlands Journal of Sea Research 27: 393-405. doi:10.1016/0077-7579 (91)90041-X.

Burke, J.S., M. Ueno, Y. Tanaka, H. Walsh, T. Maeda, I. Kinoshita, T. Seikai, D.E. Hoss, and M. Tanaka. 1998. The influence of environmental factors on early life history patterns of flounders. Netherlands Journal of Sea Research 40: 19-32.

Carr, W., and C.A. Adams. 1973. The food habits of juvenile marine fishes occupying seagrass beds in the estuarine zone near Crystal River, Florida. Transactions of the American Fisheries Society 102: 511-540. doi:10.1577/1548-8659(1973)102<511:FHOJMF> 2.0.CO;2.

Clarke, K.R., and R.N. Gorley. 2006. PRIMER v6: user manual/ tutorial. PRIMER-E, Plymouth, United Kingdom.

Clarke, K.R., and R.M. Warwick. 2001. Change in marine communities: an approach to statistical analysis and interpretation, 2nd edition. PRIMER-E, Plymouth, United Kingdom.

Doherty, P.J. 1982. Some effects of density on the juvenile of two species of tropical territorial damselfishes. Journal of Experimental Marine Biology and Ecology 65: 249-261. doi:10.1016/ 0022-0981(82)90057-0.

Folk, R.L. 1980. Petrology of sedimentary rocks. Austin, Texas: Hemphill Publishing Company.

Gibson, R.N. 1994. Impact of habitat quality and quantity on the recruitment of juvenile flatfishes. Netherlands Journal of Sea Research 322: 191-206. doi:10.1016/0077-7579(94)90040-X.

Gulf States Marine Fisheries Commission. 2000. The flounder fishery of the Gulf of Mexico, United States: A regional management plan. Publication \# 83, GSMFC, Ocean Springs, Mississippi.

Heck, K.L., and R.J. Orth. 1980. Seagrass habitats: the roles of habitat complexity, competition, competition and predation in structuring assisted fish and motile macroinvertebrate assemblages. New York, New York: Estuarine perspective. Academic Press.

Heck, K.L., and R.J. Orth. 2003. Critical evaluation of the nursery role hypothesis for seagrass meadows. Marine Ecology Progress Series 253: 123-136. doi:10.3354/meps253123.

Heck, K.L., and T.A. Thoman. 1984. The nursery role of seagrass meadows in the upper and lower reaches of the Chesapeake Bay. Estuaries 7: 70-92. doi:10.2307/1351958.

Houde, E.D. 1987. Fish early life dynamics and recruitment variability. American Fisheries Society Symposium 2: 17-29.

Keefe, M.L., and K.W. Able. 1994. Contributions of abiotic and biotic factors to settlement in summer flounder, Paralichthys dentatus. Copeia 2: 458-465. doi:10.2307/1446993. 
King, B.D. 1971. Study of migratory patterns of fish and shellfish through a natural pass. Texas Parks and Wildlife Department Technical Series 9: 1-37.

Kneib, R.T. 1984. Patterns of invertebrate distribution and abundance in the intertidal salt marsh: causes and questions. Estuaries 7: 392-412. doi: $10.2307 / 1351621$.

Kneib, R.T. 1993. Growth and mortality in successive cohorts of fish larvae within an estuarine nursery. Marine Ecology Progress Series 94: 115-127. doi:10.3354/meps094115.

Levin, P.S. 1994. Small-scale recruitment variation in temperate fish: the roles of macrophytes and food supply. Environmental Biology of Fishes 40: 271-281. doi:10.1007/BF00002517.

Levin, P.S., and M.E. Hay. 1996. Responses of temperate reef fishes to alterations in algal structure and species composition. Marine Ecology Progress Series 14: 37-47. doi:10.3354/meps134037.

Manderson, J.P., B.A. Phelan, C. Meise, L.L. Stehlik, A.J. Bejda, J. Pessutti, L. Arlen, A. Draxler, and A.W. Stoner. 2002. Spatial dynamics of habitat suitability for the growth of newly settled winter flounder Pseudopleuronectes americanus in an estuarine nursery. Marine Ecology Progress Series 228: 227-239. doi:10.3354/meps228227.

Martinez-Andrade, F., P. Campbell, and B. Fuls. 2005. Trends in relative abundance and size of Selected finfishes and shellfishes along the Texas coast: November 1975-December 2003. Management Data Series No. 232. Texas Parks and Wildlife: Coastal Fisheries Division.

Minello, T.J. 1999. Nekton densities in shallow estuarine habitats of Texas and Louisiana and the identification of essential fish habitat. American Fisheries Society Symposium 22: 43-75.

Minello, T.J., and R.J. Zimmerman. 1992. Utilization of natural and transplanted Texas salt marshes by fish and decapod crustaceans. Marine Ecology Progress Series 90: 273-285. doi:10.3354/ meps090273.

Minello, T.J., R.J. Zimmerman, and R. Medina. 1994. The importance of edge for natant macrofauna in a created salt marsh. Wetlands 14: $184-198$

Moles, A., and B.L. Norcross. 1995. Sediment preference in juvenile Pacific flatfishes. Netherlands Journal of Sea Research 34: 177182. doi:10.1016/0077-7579(95)90025-X.

Nasir, N.A., and M.G. Poxton. 2001. Substratum preferences of juvenile flatfish. Cybium 252: 109-117.

Peterson, G.W., and R.E. Turner. 1994. The value of salt marsh edge versus interior as a habitat for fish and decapod crustaceans in a Louisiana tidal marsh. Estuaries 17: 235-262. doi:10.2307/ 1352573.

Powell, A.B., and F.J. Schwartz. 1977. Distribution of paralichthids flounders (Bothidae: Paralichthys) in North Carolina estuaries. Chesapeake Science 18: 334-339. doi:10.2307/1350587.

Rooker, J.R., S.A. Holt, M.A. Soto, and G.J. Holt. 1998. Post-settlement patterns of habitat use by Sciaenid fishes in subtropical seagrass meadows. Estuaries 212: 318-327. doi:10.2307/1352478.

Rose, K.A., J.H. Cowan, K.O. Winemiller, R.A. Myers, and R. Hilbor. 2001. Compensatory density dependence in fish populations: importance, controversy, understanding and prognosis. Fish and Fisheries 2: 293-327. doi:10.1046/j.1467-2960.2001.00056.x.

Rozas, L.P., and C.T. Hackney. 1984. Use of oligohaline marshes by fishes and macrofaunal crustaceans in North Carolina. Estuaries 73: 213-224. doi:10.2307/1352141.
Rozas, L.P., and M.W. LaSalle. 1990. A comparison of the diets of gulf killifish, Fundulus grandis Baird and Girard, entering and leaving a Mississippi marsh. Estuaries 13: 332-336. doi:10.2307/1351924.

Rozas, L.P., and T.J. Minello. 1997. Estimating densities of small fishes and decapod crustaceans in shallow estuarine habitats: a review of sampling design with focus on gear selection. Estuaries 20: 199-213. doi:10.2307/1352731.

Rozas, L.P., and T.J. Minello. 1998. Nekton use of salt marsh, seagrass, and non-vegetated habitats in a south Texas (USA) estuary. Bulletin of Marine Science 63: 481-501.

Rozas, L.P., and W.E. Odum. 1988. Occupation of submerged aquatic vegetation by fishes: testing the roles of food and refuge. Oecologia 77: 101-106. doi:10.1007/BF00380932.

Sheridan, P.G., G. McMahan, K. Hammerstrom, and W. Pulich Jr. 1998. Factors affecting restoration of Halodule wrightii to Galveston Bay, Texas. Restoration Ecology 6: 144-158. doi:10.1111/j.1526-100X.1998.00625.x.

Short, F.T., and S. Wyllie-Echeverria. 1996. Natural and humaninduced disturbance of seagrasses. Environmental Conservation 23: $17-27$.

Sogard, S.M. 1992. Variability in growth rates of juvenile fishes in different estuarine habitats. Marine Ecology Progress Series 85: 35-53. doi:10.3354/meps085035.

Stokes, G.M. 1977. Life histories studies of southern flounder (Paralichthys lethostigma) and gulf flounder (P. albigutta) in the Aransas Bay area of Texas. Texas Parks and Wildlife Department Technical Series 25: 1-37.

Stunz, G.W., T.J. Minello, and P.S. Levin. 2002a. A comparison of early juvenile red drum densities among various habitat types in Galveston Bay, Texas. Estuaries 25: 76-85. doi:10.1007/ BF02696051.

Stunz, G.W., T.J. Minello, and P.S. Levin. 2002b. Growth of newly settled red drum Sciaenops ocellatus in different estuarine habitat types. Marine Ecology Progress Series 238: 227-236. doi:10.3354/meps238227.

Tanada, M. 1990. Studies on burying ability in sand and selection to the grain size for hatchery-reared marbled sole and Japanese flounder. Nippon Suisan Gakkaishi 5610: 1543-1548.

Teal, J.M. 1962. Energy flow in the salt marsh ecosystem of Georgia Ecology 43: 614-624. doi:10.2307/1933451.

Texas Parks and Wildlife Department. 2003. Saltwater finfish research and management in Texas: a report to the Governor and the 78th Legislature, Austin, Texas.

USEPA. 1999. Ecological condition of estuaries in the Gulf of Mexico. EPA 620-R-98-004. U.S. Environmental Protection Agency, Office of Research and Development, National Health and Environmental Effects Research Laboratory, Gulf Ecology Division, Gulf Breeze, Florida.

Walsh, H.J., D.S. Peters, and D.P. Cyrus. 1999. Habitat utilization by small flatfishes in a North Carolina estuary. Estuaries 22: 803813. doi:10.2307/1353113.

Weinstein, M.P. 1979. Shallow marsh habitats as primary nurseries for fishes and shellfish, Cape Fear River, North Carolina. Fishery Bulletin US 77: 339-357.

Zimmerman, R.J., T.J. Minello, M.C. Castiglione, and D.L. Smith. 1990. Utilization of marsh and associated habitats along a salinity gradient in Galveston Bay. NOAA Technical Memo, NMFSSEFC-250. 